\title{
Effect of dehydroepiandrosterone (DHEA) on vascular function in postmenopausal women with diabetes: a ran- domized controlled trial
}

\author{
Amal Shibli-Rahhal ${ }^{*}$, William Haynes ${ }^{1}$, Christine Sinkey² and Joseph S. Dillon ${ }^{1,3}$ \\ Correspondence: amal-rahhal@uiowa.edu \\ 'Division of Endocrinology, Department of Internal Medicine, Roy J. and Lucille A. Carver College of Medicine, \\ University of lowa, USA. \\ 2Department of Internal Medicine, Roy J. and Lucille A. Carver College of Medicine, University of lowa, USA. \\ ${ }^{3}$ Research Service, VA Medical Center, lowa City, lowa 52242, USA.
}

\begin{abstract}
Background: DHEA stimulates endothelial nitric oxide (NO) production in vitro and its prolonged use in humans improves vascular function. It is believed that this effect is mediated by metabolism of DHEA to androgens and estrogens. We hypothesized that DHEA action is mediated by a rapid, receptor-dependent, endothelial NO production pathway. We tested this hypothesis by studying the acute effect of a single oral dose of DHEA on vascular function in postmenopausal diabetic women.

Design and Methods: This was a double blind, randomized, placebo controlled, cross-over study. Nine postmenopausal women with type 2 diabetes and 5 age- and weight- matched controls received $50 \mathrm{mg}$ of DHEA or placebo in a random order one week apart. We examined forearm resistance vessel responses to intra-arterial nitroprusside, acetylcholine and verapamil.

Results: There was no difference in baseline characteristics and steroid hormone levels between the groups. Following administration of DHEA, steroid hormone concentrations increased in both diabetics and controls indicating adequate absorption and metabolism of DHEA. Prior to administration of arterial vasodilators, there was no difference in baseline forearm blood flow between diabetics and controls and within each group in response to DHEA versus placebo. There was also no difference in the vasodilator-induced increment in blood flow between diabetics and controls and within each group in response to DHEA versus placebo.

Conclusions: In postmenopausal women with diabetes, DHEA did not have any acute effect on basal or vasodilator stimulated forearm blood flow, despite evidence of systemic absorption and adequate vascular responses to endothelium and non-endothelium dependent vasodilators.

Keywords: vasodilator, endothelium, nitric oxide, postmenopausal
\end{abstract}

\section{Introduction}

Dehydroepiandrosterone (DHEA) and DHEA sulfate (DHEAS) have been hypothesized to decrease the risk of cardiovascular mortality and atherosclerotic disease. Extensive in vitro studies have demonstrated potentially beneficial effects of DHEA on vascular endothelium and smooth muscle [1-3], and on key mediators of atherogenesis $[4,5]$. These findings have been supported by animal studies showing anti-atherogenic and vasculotonic effects of DHEA in animal models of atherosclerosis [610]. Additionally, the majority of human epidemiological studies demonstrate an inverse correlation of plasma concentrations of DHEA or DHEAS with the prevalence of cardiovascular risk factors and cardiovascular disease [6,11-16]. Consistent with those data, daily administration of DHEA for 3 months to healthy postmenopausal women or to men with hypercholesterolemia increases endothelial dependent vasodilator function $[17,18]$. However, other long term studies of DHEA administration in humans have failed to demonstrate changes in vascular function [19-21]. We do not yet understand why the outcomes of these human studies differ from each other, or from animal and in vitro studies.

The dominant mechanistic paradigm for the actions of DHEA is that DHEA is metabolized intracellularly to other steroids, including testosterone and estradiol, which

(c) 2012 Shibli-Rahhal et al; licensee Herbert Publications Ltd. This is an open access article distributed under the terms of Creative Commons Attribution License (http://creativecommons.org/licenses/by/3.0),This permits unrestricted use, distribution, and reproduction in any medium, provided the original work is properly cited. 
activate gene transcription via androgen or estrogen receptors. While many effects of DHEA are mediated by its metabolism to potent androgens and estrogens [22], there are extensive data from in vitro and in vivo models which favor vascular effects of DHEA that are not dependent on metabolic conversion $[10,23,24]$. Unlike estradiol and testosterone, there is as yet no unequivocally characterized receptor for DHEA. However, we have pharmacologically characterized a high affinity, saturable, DHEA-specific receptor, expressed on the plasma membranes of vascular endothelial and other cells [23]. Receptor activation by physiological concentrations of DHEA rapidly increases endothelial production of nitric oxide (NO), a key molecule in healthy vascular function $[23,25,26]$. Consistent with this action on cellular NO production, endothelial cell cGMP production is also increased within minutes $[23,27]$.

The inconsistent outcomes from DHEA administration in humans may be related to experimental designs that are based on the putative mechanism of DHEA action i.e., that effects of DHEA are mediated via its metabolism to potent androgens and estrogens which activate their specific receptors. Based on that mechanism of action, it is reasonable to expect a long lasting effect of the steroid after chronic exposure. However, if the mechanism is one of rapid activation of NO production, then the study should be designed to detect a short term signal. Based on our experimental data, and in contrast to previous human studies of DHEA administration, we tested an alternative mechanistic hypothesis for DHEA action i.e., that the effects of DHEA in the vasculature were mediated by a rapid, receptor-dependent, endothelial NO production pathway. We tested our hypothesis by studying the acute effect of a single oral dose of DHEA on vascular function in a group of postmenopausal women with type 2 diabetes, since diabetes and aging are associated with endothelial dysfunction $[\mathbf{2 8 , 2 9 ]}$ and with lower blood levels of DHEA and DHEAS [30].

\section{Materials and methods}

\section{Study design}

This was a double-blinded, randomized, placebo-controlled, crossover pilot study to test the effects of a single $50 \mathrm{mg}$ dose of DHEA on vascular reactivity. This dose was chosen because it was shown to achieve DHEA blood levels in the upper physiological range for young individuals and is the dose most frequently used in recent clinical trials [31-33]. All interactions with study volunteers took place in the General Clinical Research Center (GCRC) at the University of lowa Hospitals and Clinics. The study was approved by the Human Research Protection Office at the University of lowa College of Medicine.

\section{Subjects}

Two groups of postmenopausal women were recruited from the databases available at the University of lowa GCRC Vascular Laboratory and the Diabetes Research Trials Office and by advertisement in University newspapers. One group included women with type 2 diabetes mellitus, aged 40-75 years, and the other group included age- and weight-matched controls without diabetes. Exclusion criteria for all subjects included clinical evidence of cardiovascular disease (based on history, physical examination and electrocardiogram), history of breast or ovarian cancer, tobacco use in the year preceding the study, coagulopathy, and vasculitis. Additional exclusion criteria for the control group included hypertension and hypercholesterolemia. Post-menopausal state was defined by a duration of one year or longer since the last menstrual period (in the absence of pregnancy), or a history of surgical oophorectomy with or without hysterectomy, at least 6 months prior to signing the informed consent.

\section{Study Procedures}

Signed and witnessed consent was documented from all participants prior to any study interventions. Subjects attended a screening session for history and physical examination. Qualifying subjects subsequently returned for two study visits, at least 1 week apart. The two study visits were identical with the only difference being that the subjects received $50 \mathrm{mg}$ of oral DHEA on one visit and a matching placebo on the other visit in random order. The DHEA and placebo capsules were compounded by a local pharmacy. Replacement therapy with estrogen was held for one week prior to enrolling in the study and throughout the study. Vitamins in excess of one multivitamin per day and vitamins containing herbs or hormones were held for four weeks prior to enrolling in the study and throughout the study. Subjects abstained from alcohol for 24 hours and coffee for 12 hours before each study visit.

On each study visit, baseline levels of fasting glucose, DHEA, DHEAS, estradiol and total testosterone were obtained. The subjects subsequently received DHEA or placebo in random order. Testing of resistance vessel endothelial function was started 30 minutes after administration of the study medication. Plasma levels of glucose, DHEA, DHEAS, estradiol and total testosterone were repeated 30 minutes after the administration of the study medication and at the end of the resistance vessel endothelial function test (figure 1). Pharmacokinetic studies have shown that, after one $50 \mathrm{mg}$ oral dose of DHEA, the level of DHEA peaks at approximately one hour, is maintained at young adult high physiological levels for four hours and then starts declining gradually $[31,32]$. Since the vascular endothelial function study was performed within four hours after taking DHEA, we assume that the DHEA plasma concentration remained relatively stable at young adult high physiological levels throughout the study. However it is important to note that these pharmacokinetic 
Figure 1. Schematic showing detailed protocol for investigation of the effect of DHEA on endothelial function

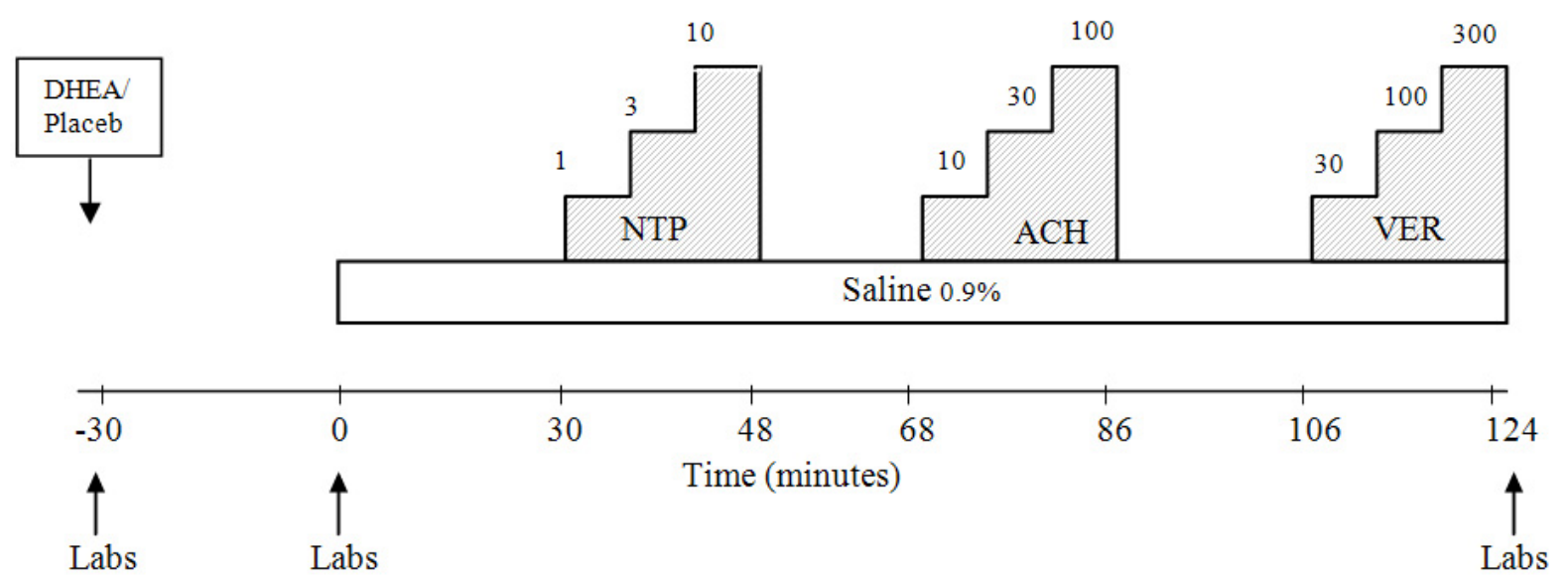

The numbers above each column represent medication doses in $\mu \mathrm{g} / \mathrm{min}$. DHEA/placebo=dehydroepiandrosterone/placebo; $\mathrm{NTP}=$ nitroprusside; $\mathrm{ACH}=$ acetylcholine; $\mathrm{VER}=$ verapamil. Labs=fasting insulin, fasting glucose, DHEA, DHEAS, estradiol and total testosterone at -30 minutes; and glucose, DHEA, DHEAS, estradiol and total testosterone at 0 minutes and 124 minutes.

studies were performed in young women of normal body mass index (BMI) [31] or in older men [32] and that potential differences in the DHEA level may exist between these groups and our study population given the differences in age, gender and body fat.

\section{Resistance vessel endothelial function}

Forearm blood flow was measured by venous occlusion plethysmography at baseline and in response to local intra-arterial administration of nitroprusside, acetylcholine and verapamil. Drugs were administered via a $27-$ gage stainless steel catheter inserted into the brachial artery under local anesthesia. All drugs were dissolved in $0.9 \%$ saline. Nitroprusside $(1,3$ and $10 \mu \mathrm{g} / \mathrm{min})$, acetylcholine (10, 30 and $100 \mu \mathrm{g} / \mathrm{min})$, and verapamil $(30,100,300$ $\mu \mathrm{g} / \mathrm{min}$ ) were sequentially infused allowing time for forearm blood flow to return to basal between drugs (figure 1). Acetylcholine was used to evaluate endotheliumdependent vasodilatation, and nitroprusside (nitric oxide donor, endothelium independent) and verapamil (nitric oxide independent) were used to evaluate endotheliumindependent vasodilatation.

\section{Laboratory Data}

All laboratory assays except DHEA were performed in the clinical chemistry laboratory of the University of lowa Hospitals and Clinics. HbA1c was determined by turbidimetric inhibition immunoassay (TINIA) (lower detection limit $0.2 \mathrm{~g}$ /
$\mathrm{dL}$; intra-assay coefficient of variability (CV) $2.1 \%$; interassay CV 3.1\%; Roche Diagnostics). Plasma creatinine was determined by enzymatic calorimetric assay (lower detection limit $0.03 \mathrm{mg} / \mathrm{dL}$; intra-assay CV 0.9\%; inter-assay CV 1.1\%; Roche Diagnostics). Total cholesterol, HDL-cholesterol and triglycerides were determined by enzymatic calorimetric assay reaction (lower detection limit $3 \mathrm{mg} / \mathrm{dL}, 0.08 \mathrm{mg} /$ $\mathrm{dL}$, and $4 \mathrm{mg} / \mathrm{dL}$ respectively; intra-assay CV $0.8 \%, 0.95 \%$ and $1.8 \%$ respectively; and inter-assay CV $1.7 \%, 1.3$ and $1.5 \%$ respectively; Roche Diagnostics). Serum levels oF, DHEAS, estradiol and total testosterone were measured using electrochemiluminescence immunoassay (ECLIA) (lower detection limits $0.1 \mu \mathrm{g} / \mathrm{dl}, 5.0 \mathrm{pg} / \mathrm{mL}$ and $2.5 \mathrm{ng} / \mathrm{dL}$ respectively; intra-assay CV 2.7\%, 2.4\% and 5.35 respectively; inter-assay CV $2.5 \%, 3.1 \%$ and $6.3 \%$ respectively; Roche Diagnostics).

DHEA was mailed to a reference laboratory where it was determined by liquid chromatography-mass spectrometry (LC-MS/MS) (lower detection limit $10.0 \mathrm{ng} / \mathrm{dL}$; intra-assay CV 7.3\%; inter-assay CV 10.0\%; Quest Diagnostics).

\section{Statistical analysis}

Our primary variable of interest was the difference in brachial artery dilatation, induced by DHEA administration, in response to intra-arterial vasodilators. We used nonparametric bivariate methods to compare the demographic characteristics and baseline laboratory data between diabetics and controls. 
Within each group of patients (diabetics and control), we also estimated the mean concentrations of DHEA, DHEAS, estradiol and testosterone at baseline, at 30 minutes and at the end of the vascular function study on both study days (placebo day and DHEA day). Then, for each hormone, we compared the end of study concentration to the baseline concentration using nonparametric bivariate analyses in order to confirm adequate absorption and metabolism of DHEA on the day when DHEA was administered. To further verify adequate absorption and metabolism of DHEA, we also reported the baseline and end of study hormone concentrations as a percentile of the normal range of young adults. The percentile was calculated by subtracting the lower end of the normal range of young adults from the hormone concentration in question, then dividing the result by the range of the normal adult levels (upper limit- lower limit).

We then compared changes in basal and post-vasodilator forearm blood flow following DHEA and placebo administration within each group and between the 2 groups, using nonparametric statistical analyses. All analyses were conducted using SAS for Windows, version 9.2 (SAS Institute Inc., Cary, NC).

\section{Results}

We initially enrolled 10 subjects with type 2 diabetes and 5 age- and weight- matched controls, but one of the diabetic subjects withdrew from the study before undergoing endothelial function testing because she could not tolerate estrogen withdrawal. The final study population consisted of 9 diabetic subjects and 5 controls. The number of subjects was empirically chosen given that this was a pilot study. All patients were Caucasians except for 1 subject of Hispanic descent in the control group. Baseline characteristics of the study subjects are found in Table 1. The mean glycosylated hemoglobin was $7.0 \%$ in the diabetics and $5.6 \%$ in the controls. Subjects with diabetes had a higher mean baseline DHEA concentration compared to controls (8.5 versus 3.0 $\mathrm{ng} / \mathrm{ml}$, p-value 0.02 ), and a lower testosterone concentration (15.2 versus $38.3, p$-value 0.03 ). There was no significant difference between the two groups with respect to age, body mass index, blood pressure, and lipid parameters.

Table 2 shows the concentrations of DHEA, DHEAS, estradiol and total testosterone in the diabetic and control groups. Baseline hormone concentrations were obtained before subjects took the study medication (DHEA or placebo), and were repeated 30 minutes later and at the end of the vascular function study. When subjects received placebo, there was no increase in the hormone concentrations from baseline. Following administration of DHEA, an increase in the steroid hormone concentrations was seen indicating adequate absorption and metabolism of DHEA. Plasma DHEA concentrations increased from the $28^{\text {th }}$ percentile to the $80^{\text {th }}$ percentile of the normal range of young adults (1.6 to $8.0 \mathrm{ng} / \mathrm{ml}$ ) in the diabetic group (cumulative increase of $97 \%, p$-value 0.03 ), and from the $21^{\text {st }}$ percentile to the $100^{\text {th }}$ percentile in the non-diabetic group (cumulative increase of $186 \%$, p-value 0.03 ). Plasma DHEAS concentrations

Table 1. Characteristics of study subjects

\begin{tabular}{llll}
\hline & \multicolumn{2}{c}{ Mean \pm SD (95\% CI) } & p-value \\
\cline { 2 - 4 } Number & \multicolumn{1}{c}{ Diabetics } & \multicolumn{1}{c}{ Controls } \\
Age (years) & \multicolumn{1}{c}{$91.4 \pm 4.4(58.5-64.3)$} & $58.0 \pm 3.8(54.7-61.3)$ & 0.17 \\
BMI & $35.3 \pm 5.4(31.8-38.8)$ & $32.4 \pm 2.9(29.9-34.9)$ & 0.30 \\
HbA1c (\%) & $7.0 \pm 1.1(6.3-7.7)$ & $5.6 \pm 0.2(5.4-5.8)$ & 0.02 \\
SBP (mmHg) & $132.2 \pm 22.2(117.7-146.7)$ & $117.0 \pm 14.3(104.5-129.5)$ & 0.20 \\
DBP $(\mathrm{mmHg})$ & $71.1 \pm 9.9(64.6-77.6)$ & $69.6 \pm 7.6(62.9-76.3)$ & 0.77 \\
TC $(\mathrm{mg} / \mathrm{dl})$ & $177.0 \pm 13.8(168.0-186.0)$ & $184.8 \pm 22.7(164.9-204.7)$ & 0.43 \\
LDL $(\mathrm{mg} / \mathrm{dl})$ & $90.1 \pm 16.7(79.2-101.0)$ & $89.4 \pm 16.0(75.4-103.4)$ & 0.94 \\
HDL $(\mathrm{mg} / \mathrm{dl})$ & $58.9 \pm 11.8(51.2-66.6)$ & $71.8 \pm 9.9(63.1-80.5)$ & 0.06 \\
TG $(\mathrm{mg} / \mathrm{dl})$ & $140.4 \pm 66.0(96.9-183.1)$ & $112.6 \pm 24.9(90.8-134.4)$ & 0.39 \\
Cr $(\mathrm{mg} / \mathrm{dl})$ & $0.7 \pm 0.1(0.6-0.8)$ & $0.7 \pm 0.1(0.6-0.8)$ & 0.98 \\
DHEA $(\mathrm{ng} / \mathrm{ml})$ & $8.5 \pm 3.8(6.0-11.0)$ & $3.0 \pm 1.3(1.9-4.1)$ & 0.02 \\
DHEAS $(\mu \mathrm{gg} / \mathrm{dl})$ & $61.3 \pm 34.8(38.6-84.0)$ & $98.2 \pm 105.9(5.4-191.0)$ & 0.50 \\
Estradiol $(\mathrm{pg} / \mathrm{ml})$ & $7.2 \pm 4.6(4.2-10.2)$ & $4.7 \pm 6.3(0-10.2)$ & 0.20 \\
Testosterone $(\mathrm{ng} / \mathrm{dl})$ & $15.2 \pm 6.8(10.8-19.6)$ & $38.2 \pm 14.6(25.4-51.0)$ & 0.03 \\
\hline
\end{tabular}


increased from below the normal range to the $32^{\text {nd }}$ percentile of the normal range of young adults $(280-640 \mu \mathrm{g} / \mathrm{dl})$ in the diabetic group (cumulative increase of 599\%, p-value 0.001), and from below the normal range to the $47^{\text {th }}$ percentile in the non-diabetic group (cumulative increase of 394\%, $\mathrm{p}$-value 0.02 ). Total testosterone concentrations remained within the normal range for females $(<82 \mathrm{ng} / \mathrm{dl})$, increasing by $67 \%$ in the diabetic group ( $p$-value 0.01 ) and by $46 \%$ in the non-diabetic group ( $p$-value 0.20 ). Total estradiol concentrations remained within the normal range for postmenopausal females $(<54 \mathrm{pg} / \mathrm{ml})$, increasing by 200 $\%$ in the diabetic group ( $p$-value 0.01 ) and by $396 \%$ in the non-diabetic group ( $p$-value 0.09).

Prior to administration of arterial vasodilators, there was no difference in baseline forearm blood flow between diabetics and controls. In addition, no significant difference in baseline blood flow was seen within each group in response to DHEA versus placebo (figure 2).

Tables 3 and $\mathbf{4}$ show the mean percent increase from baseline in forearm blood flow in response to maximal doses of intra-arterial nitroprusside $(10 \mu \mathrm{g} / \mathrm{minute})$, acetylcholine (30 $\mathrm{gg} /$ minute) and verapamil ( $300 \mu \mathrm{g} /$ minute). There was no difference in the vasodilator-induced increment in blood flow between those ingesting DHEA and those ingesting placebo, within either the diabetic or control groups (table 3). In addition, when comparing the diabetic to the control group, there was no significant difference in vasodilator-induced increment in blood flow after administration of DHEA and placebo, although diabetics showed a trend toward an increased response to all vasodilators (table 4).

\section{Discussion}

Our study shows that administration of DHEA has no acute effect on endothelial function in postmenopausal women with and without type 2 diabetes despite evidence of adequate absorption of DHEA, as demonstrated by the increase in plasma concentrations of DHEA and DHEAS. The lack of response was seen both at baseline and after intraarterial infusion of vasodilators with different mechanisms of action.

These results are in disagreement with two recent placebo controlled studies that demonstrated a significant improvement in endothelium-mediated vasodilation following administration of DHEA. Williams et al., showed that daily supplementation of healthy postmenopausal women with $100 \mathrm{mg}$ of DHEA for 3 months leads to a significant improvement in endothelial-mediated vascular dilation [17]. A similar study by Kawano et al. demonstrated that daily administration of $25 \mathrm{mg}$ of DHEA to middle-aged

Table 2. Steroid hormone concentrations at baseline, 30 minutes after administration of study medication and at the end of the forearm blood flow study in diabetics and controls

\begin{tabular}{|c|c|c|c|c|c|c|c|c|}
\hline & \multicolumn{8}{|c|}{ Hormone level \pm SD $(95 \% \mathrm{CI})$} \\
\hline & \multicolumn{4}{|c|}{ Diabetics $(n=9)$} & \multicolumn{4}{|c|}{ Controls $(n=5)$} \\
\hline & baseline & 30 minutes & End of study & p-value ${ }^{\star}$ & baseline & 30 minutes & End of study & p-value ${ }^{\star}$ \\
\hline \multicolumn{9}{|c|}{ DHEA $(\mathrm{ng} / \mathrm{ml})$} \\
\hline Placebo & $\begin{array}{c}8.5 \pm 3.8 \\
(6.0-11.0)\end{array}$ & $\begin{array}{l}9.5 \pm 7.9 \\
(4.3-14.7)\end{array}$ & $\begin{array}{c}8.7 \pm 7.1 \\
(4.1-13.3)\end{array}$ & 0.80 & $\begin{array}{l}3.0 \pm 1.3 \\
(1.9-4.1)\end{array}$ & $\begin{array}{l}2.1 \pm 1.1 \\
(1.1-3.1)\end{array}$ & $\begin{array}{l}2.0 \pm 0.8 \\
(1.3-2.7)\end{array}$ & 0.50 \\
\hline DHEA & $\begin{array}{l}3.4 \pm 1.2 \\
(2.6-4.2)\end{array}$ & $\begin{array}{l}5.4 \pm 3.0 \\
(3.4-7.4)\end{array}$ & $\begin{array}{l}6.7 \pm 4.2 \\
(4.0-9.4)\end{array}$ & 0.03 & $\begin{array}{l}2.8 \pm 1.5 \\
(1.5-4.1)\end{array}$ & $\begin{array}{c}9.8 \pm 9.5 \\
(1.5-18.1)\end{array}$ & $\begin{array}{c}8.0 \pm 3.9 \\
(4.6-11.4)\end{array}$ & 0.03 \\
\hline \multicolumn{9}{|c|}{ DHEAS $(\mu \mathrm{g} / \mathrm{dl})$} \\
\hline Placebo & $\begin{array}{l}61.3 \pm 34.8 \\
(38.6-84.0)\end{array}$ & $\begin{array}{l}58.8 \pm 33.2 \\
(37.1-80.5)\end{array}$ & $\begin{array}{l}58.7 \pm 32.1 \\
(37.7-79.7)\end{array}$ & 0.90 & $\begin{array}{c}98.2 \pm 105.9 \\
(5.4-191.0)\end{array}$ & $\begin{array}{l}61.8 \pm 43.0 \\
(24.1-99.5)\end{array}$ & $\begin{array}{l}56.5 \pm 45.5 \\
(16.6-96.4)\end{array}$ & 0.72 \\
\hline DHEA & $\begin{array}{l}56.7 \pm 27.3 \\
(38.9-74.5)\end{array}$ & $\begin{array}{l}117.1 \pm 90.7 \\
(57.8-176.4)\end{array}$ & $\begin{array}{c}396.3 \pm 97.3 \\
(332.7-459.9)\end{array}$ & 0.001 & $\begin{array}{c}90.6 \pm 64.7 \\
(33.3-146.7)\end{array}$ & $\begin{array}{c}180.0 \pm 104.4 \\
(88.5-271.5)\end{array}$ & $\begin{array}{l}447.5 \pm 167.3 \\
(300.9-594.1)\end{array}$ & 0.02 \\
\hline \multicolumn{9}{|c|}{ Estradiol $(\mathrm{pg} / \mathrm{ml})$} \\
\hline Placebo & $\begin{array}{c}7.2 \pm 4.6 \\
(4.2-10.2)\end{array}$ & $\begin{array}{l}7.1 \pm 4.6 \\
(4.1-10.1)\end{array}$ & $\begin{array}{l}7.5 \pm 5.2 \\
(4.1-10.9)\end{array}$ & 0.98 & $\begin{array}{c}4.7 \pm 6.3 \\
(0-10.2)\end{array}$ & $\begin{array}{l}2.1 \pm 1.1 \\
(1.1-3.1)\end{array}$ & $\begin{array}{l}4.3 \pm 4.1 \\
(0.7-7.9)\end{array}$ & 0.99 \\
\hline DHEA & $\begin{array}{l}6.7 \pm 4.3 \\
(3.9-9.5)\end{array}$ & $\begin{array}{l}7.2 \pm 3.9 \\
(4.7-9.8)\end{array}$ & $\begin{array}{l}20.3 \pm 10.1 \\
(13.7-26.9)\end{array}$ & 0.01 & $\begin{array}{c}5.0 \pm 5.6 \\
(0-9.9)\end{array}$ & $\begin{array}{l}3.5 \pm 2.9 \\
(1.0-6.0)\end{array}$ & $\begin{array}{c}24.8 \pm 26.9 \\
(1.2-48.4)\end{array}$ & 0.09 \\
\hline \multicolumn{9}{|c|}{ Testosterone $(\mathrm{ng} / \mathrm{dl})$} \\
\hline Placebo & $\begin{array}{c}15.2 \pm 6.8 \\
(10.8-19.6)\end{array}$ & $\begin{array}{c}14.4 \pm 6.4 \\
(10.2-18.6)\end{array}$ & $\begin{array}{l}14.0 \pm 7.0 \\
(9.4-18.6)\end{array}$ & 0.90 & $\begin{array}{l}38.2 \pm 14.7 \\
(25.3-51.1)\end{array}$ & $\begin{array}{l}39.0 \pm 13.8 \\
(26.9-51.1)\end{array}$ & $\begin{array}{c}43.6 \pm 6.3 \\
(38.1-49.1)\end{array}$ & 0.60 \\
\hline DHEA & $\begin{array}{l}18.0 \pm 10.5 \\
(11.1-24.9)\end{array}$ & $\begin{array}{c}19.3 \pm 5.2 \\
(15.9-22.7)\end{array}$ & $\begin{array}{l}30.0 \pm 14.0 \\
(20.9-39.2)\end{array}$ & 0.01 & $\begin{array}{l}41.2 \pm 20.4 \\
(23.3-59.1)\end{array}$ & $\begin{array}{l}57.2 \pm 30.5 \\
(30.5-83.9)\end{array}$ & $\begin{array}{l}60.2 \pm 22.0 \\
(40.9-79.5)\end{array}$ & 0.20 \\
\hline
\end{tabular}

* p-value compares baseline level to end of study level after ingestion of placebo or DHEA within each group (diabetic and control subjects). 


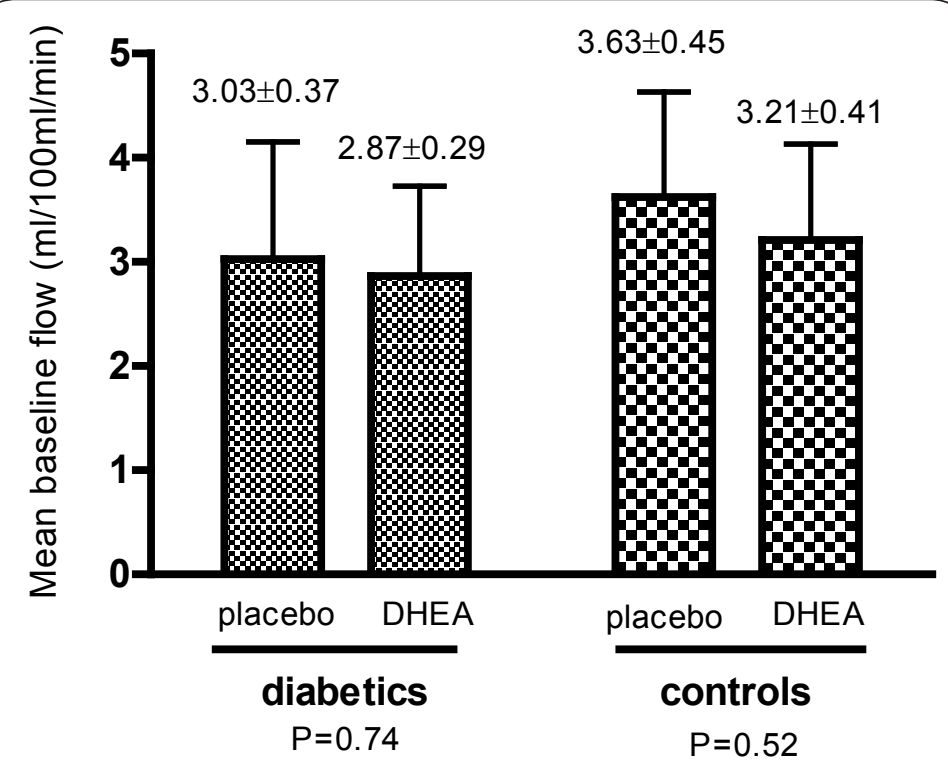

Figure 2. Baseline blood flow prior to administration of intraarterial vasodilators

Table 3. Response to maximal intra-arterial doses of vasodilators in diabetics and controls with DHEA versus placebo

\begin{tabular}{l|c|c|c}
\hline \multirow{2}{*}{ Vasodilator } & Percent increase in blood flow from baseline \pm SD & P-value \\
\cline { 2 - 3 } & DHEA & Placebo & \\
\hline \multicolumn{4}{c}{ Diabetics } \\
\hline NTP $10 \mu \mathrm{g} / \mathrm{min}$ & $317.6 \pm 87.9$ & $364.8 \pm 98.3$ & 0.30 \\
ACH $100 \mu \mathrm{g} / \mathrm{min}$ & $413.7 \pm 156.8$ & $479.5 \pm 118.2$ & 0.30 \\
VER $300 \mu \mathrm{g} / \mathrm{min}$ & $449.0 \pm 169.7$ & $462.2 \pm 77.5$ & 0.60 \\
\hline \multicolumn{4}{c}{ Controls } \\
\hline NTP $10 \mu \mathrm{g} / \mathrm{min}$ & $277.8 \pm 117.3$ & $275.5 \pm 66.7$ & 0.70 \\
ACH $100 \mu \mathrm{g} / \mathrm{min}$ & $342.8 \pm 148.6$ & $334.0 \pm 108.6$ & 1.00 \\
VER $300 \mu \mathrm{g} / \mathrm{min}$ & $323.1 \pm 69.7$ & $356.6 \pm 54.2$ & 0.70 \\
\hline
\end{tabular}

Table 4. Response to maximal intraarterial doses of vasodilators after DHEA and placebo in diabetics versus controls

\begin{tabular}{l|c|c|c}
\hline \multirow{2}{*}{ Vasodilator } & Percent increase in blood flow from baseline \pm SD & \multirow{2}{*}{ P-value } \\
\cline { 2 - 3 } & Diabetics & Controls & \\
\hline \multicolumn{4}{|c}{ DHEA } \\
\hline NTP $10 \mu \mathrm{g} / \mathrm{min}$ & $317.6 \pm 88.0$ & $277.8 \pm 117.3$ & 0.40 \\
ACH $100 \mu \mathrm{g} / \mathrm{min}$ & $413.7 \pm 156.8$ & $342.8 \pm 148.6$ & 0.40 \\
VER $300 \mu \mathrm{g} / \mathrm{min}$ & $448.9 \pm 169.7$ & $323.1 \pm 69.7$ & 0.20 \\
\hline \multicolumn{4}{|c}{ Placebo } \\
\hline NTP $10 \mu \mathrm{g} / \mathrm{min}$ & $364.8 \pm 98.3$ & $275.5 \pm 66.7$ & 0.10 \\
ACH $100 \mu \mathrm{g} / \mathrm{min}$ & $479.5 \pm 118.2$ & $334.0 \pm 108.6$ & 0.06 \\
VER $300 \mu \mathrm{g} / \mathrm{min}$ & $462.2 \pm 77.5$ & $356.6 \pm 54.2$ & 0.05 \\
\hline
\end{tabular}


men with hypercholesterolemia for 12 weeks improved flow mediated vasodilation of the brachial artery [18].

It should however be noted that other investigators have been unable to replicate the findings of Kawano et al., and Williams et al., In studies of 12-26 weeks with $50 \mathrm{mg}$ of DHEA administered to individuals with hypoadrenalism, Rice et al., [19] and Christiansen et al., [20] could not demonstrate an improvement in endothelial function or indices of arterial stiffness despite normalization of androgen levels. Likewise, Marder et al., found no improvement in vascular endothelial function in patients with systemic lupus erythematosus (SLE) treated with $200 \mathrm{mg}$ daily of DHEA for 12 weeks [21]. One of the reasons for these discrepancies may reside in the concomitant use of glucocorticoids in patients with hypoadrenalism $[19,20]$ and in $5 / 8$ patients with SLE [21], since glucocorticoids may be antagonistic to DHEA [34].

Possible explanations for the discrepancy between our results and those of the clinical studies that showed improvement in endothelial function in response to DHEA may reside in the basic design of the studies. Williams et al., and Kawano et al. tested the effect of chronic use of DHEA on vascular function, while we assessed the acute effect of single oral doses of the compound. Although in vitro data by our group and others suggests a potent effect of DHEA to activate the endothelial nitric oxide synthase (eNOS) and increase NO production within minutes of steroid exposure in isolated bovine aortic endothelial cells (BAEC) or in human umbilical vein endothelial cells $[23,25]$, Williams et al., showed that DHEA increased the expression of eNOS protein in BAEC in a time dependent fashion, with a maximum response seen after 16 hours [17]. It is thus possible that the rapid actions of DHEA noted in studies on isolated endothelial cells are insufficient to achieve an enhanced vasodilator effect, whereas a longer exposure to DHEA- which might increase eNOS protein expression in addition to enzyme activation- is needed to induce favorable changes in endothelial function in vivo.

Finally, while stimulation of NO release has been noted in isolated vascular endothelial cells, the vasodilator response in vivo is dependent on the net action of both vasodilator and vasoconstrictor substances and neural influences. The in vitro studies by Formoso et al., [26] raise the possibility that DHEA may induce the production and secretion of both the vasodilator $\mathrm{NO}$ and the vasoconstrictor endothelin 1 ; the balance of these secretions will govern the vascular response in any specific vascular bed. It is of interest that Molinari et al. found that DHEA caused coronary, mesenteric, renal and iliac vasoconstriction in anesthetized pigs, through a mechanism involving inhibition of the vasodilatory $\beta_{2}-$ adrenergic receptor effect $[35,36]$.

Our analysis was limited by the small number of subjects in both study groups. In addition, estrogen replacement therapy was withheld for 1 week prior to initiation of the study, although the effects of estrogen on sex hormone binding globulin (SHBG) and testosterone may last for much more time, a factor that could have affected the subjects' response to DHEA. However, only 1 subject enrolled in the diabetic group was on estrogen and she could not tolerate the symptoms of estrogen withdrawal (hot flashes) and withdrew from the study before she underwent randomization and any of the vascular studies. All other subjects were not on estrogen replacement therapy prior to enrolling in the study, so the effect of prior estrogen therapy on vascular function is not a contributing factor to the observed response.

Another potential confounding factor is the difference in baseline concentrations of DHEA and testosterone between diabetics and controls. The basal DHEA concentration was significantly higher in diabetics than controls on the day of administration of placebo (tables 1 and 2), but not on the day when subjects received the DHEA capsule (table 2). Unfortunately we do not have a clear explanation for this discrepancy but it could simply be due to the small sample size. However, since both diabetics and controls had similar baseline DHEA concentrations on the day they received DHEA, we do not think that these variations in basal DHEA concentrations affected the vascular response to DHEA.

Unlike the DHEA concentrations, the difference in mean testosterone between the diabetic and control groups was similar on the days where placebo and DHEA were administered, with levels in the diabetic group about $40 \%$ of those in the control group. One possible explanation is the fact that 55\% (5/9) diabetic subjects were on metformin while none of the controls took metformin, which has been shown to decrease total testosterone [37]. Additionally, lower SHBG is an independent predictor of type 2 diabetes, so while total testosterone is lower we do not know what the free testosterone level is [38]. However, it remains unclear whether there is an effect of endogenous testosterone in women and what the specific effects are. Studies have shown no impact on cardiovascular mortality in women [39], an inverse correlation of endogenous testosterone with cardiovascular risk markers [40], or even association of total testosterone with carotid intima media thickness and arterial stiffness [41]. Given the lack of clarity in the literature we cannot speculate on the potential role of the testosterone differences on the results.

In summary, DHEA administration has no acute effects on vascular function in postmenopausal women with and without type 2 diabetes. This result is not consistent with the hypothesis that the positive vascular functional effects of DHEA, evident in some long term studies $[17,18]$, were mediated by rapid stimulation of endothelial NO production. Whether effects of DHEA on vascular function are mediated by increases in eNOS protein expression up to 16 hours after the ingestion of DHEA [17] remains to be determined. 


\section{List of abbreviations}

BAEC: bovine aortic endothelial cells

CGMP: cyclic guanosine monophosphate

DHEA: dehydroepiandrosterone

DHEAS: dehydroepiandrosterone sulfate

eNOS: endothelial nitric oxide synthase

GCRC: General Clinical Research Center

NO: nitric oxide

SAS ${ }^{\bullet}$ : Statistical Analysis Software

SLE: systemic lupus erythematosus

Competing interests

The authors have no conflict of interest to disclose.

\section{Authors' contributions}

All authors took part in the conception and design of the study; analysis and interpretation of data; drafting of the article or revising it critically for important intellectual content and final approval of the version to be published.

\section{Acknowledgements}

The studies were supported by a grant M01 RR00059 (NCRR, $\mathrm{NIH)}$. The research was also supported by the Department of Veterans Affairs, Veterans Health Administration, Office of Research and Development, Biomedical Laboratory Research and Development Program. The contents do not represent the views of the Department of Veterans Affairs or the United States Government.

Publication history

Received: 20-Aug-2012 Revised: 19-Sep-2012

Accepted: 20-Sep-2012 Published: 18-Oct-2012

\section{References}

1. Barbagallo M, Shan J, Pang PK, Resnick LM: Effects of dehydroepiandrosterone sulfate on cellular calcium responsiveness and vascular contractility. Hypertension 1995, 26:1065-1069. | Article| PubMed

2. Yoneyama A, Kamiya Y, Kawaguchi M, Fujinami T: Effects of dehydroepiandrosterone on proliferation of human aortic smooth muscle cells. Life Sci 1997, 60:833-838. | Article| PubMed

3. Mohan PF, Benghuzzi $\mathrm{H}$ : Effect of dehydroepiandrosterone on endothelial cell proliferation. Biomed Sci Instrum 1997, 33:550-555. I PubMed

4. Khalil A, Lehoux JG, Wagner RJ, Lesur O, Cruz S, Dupont E, Jay-Gerin $J P$, Wallach J, Fulop T: Dehydroepiandrosterone protects low density lipoproteins against peroxidation by free radicals produced by gamma-radiolysis of ethanol-water mixtures. Atherosclerosis 1998, 136:99-107. | Article| PubMed

5. Mohan PF, Jacobson MS: Inhibition of macrophage superoxide generation by dehydroepiandrosterone. Am J Med Sci 1993, 306:10-15. | Article| PubMed

6. Alexandersen P, Haarbo J, Christiansen C: The relationship of natural androgens to coronary heart disease in males: a review. Atheroscle rosis 1996, 125:1-13. | Article| PubMed

7. Gordon GB, Bush DE, Weisman HF: Reduction of atherosclerosis by administration of dehydroepiandrosterone. $A$ study in the hypercholesterolemic New Zealand white rabbit with aortic intimal injury. J Clin Invest 1988, 82:712-720. | Article| PubMed Abstract | PubMed Full Text

8. Yorek MA, Coppey LJ, Gellett JS, Davidson EP, Bing X, Lund DD, Dillon JS: Effect of treatment of diabetic rats with dehydroepiandrosterone on vascular and neural function. Am J Physiol Endocrinol Metab 2002, 283:E1067-1075. | Article| PubMed

9. Arad Y, Badimon JJ, Badimon L, Hembree WC, Ginsberg HN: Dehydro- epiandrosterone feeding prevents aortic fatty streak formation and cholesterol accumulation in cholesterol-fed rabbit. Arteriosclerosis 1989, 9:159-166. | Article| PubMed

10. Bonnet S, Paulin R, Sutendra G, Dromparis P, Roy M, Watson KO, Nagendran J, Haromy A, Dyck JR, Michelakis ED: Dehydroepiandrosterone reverses systemic vascular remodeling through the inhibition of the Akt/GSK3-\{beta\}/NFAT axis. Circulation 2009, 120:1231-1240. | Article| PubMed

11. Shufelt C, Bretsky P, Almeida CM, Johnson BD, Shaw $L$, Azziz R, Braunstein GD, Pepine CJ, Bittner V, Vido DA, Stanczyk FZ, Bairey Merz CN: DHEA-S levels and cardiovascular disease mortality in postmenopausal women: results from the National Institutes of Health--National Heart, Lung, and Blood Institute (NHLBI)-sponsored Women's Ischemia Syndrome Evaluation (WISE). J Clin Endocrinol Metab 2010, 95:4985-4992. | Article| PubMed Abstract | PubMed Full Text

12. Young $D G$, Skibinski $G$, Mason JI, James $K$ : The influence of age and gender on serum dehydroepiandrosterone sulphate (DHEA-S), IL-6, IL-6 soluble receptor (IL-6 sR) and transforming growth factor beta 1 (TGF-beta1) levels in normal healthy blood donors. Clin Exp Immunol 1999, 117:476-481. | Article| PubMed Abstract | PubMed Full Text

13. Trivedi DP, Khaw KT (2001) Dehydroepiandrosterone sulfate and mortality in elderly men and women. J Clin Endocrinol Metab 86: 41714177. | Article | PubMed Abstract | PubMed Full Text

14. Feldman HA, Johannes CB, Araujo AB, Mohr BA, Longcope C, McKinlay JB: Low dehydroepiandrosterone and ischemic heart disease in middle-aged men: prospective results from the Massachusetts Male Aging Study. Am J Epidemiol 2001, 153:79-89. | Article| PubMed

15. Herrington DM, Gordon GB, Achuff SC, Trejo JF, Weisman HF, Kwiterovich PO, Jr., Pearson TA: Plasma dehydroepiandrosterone and dehydroepiandrosterone sulfate in patients undergoing diagnostic coronary angiography. J Am Coll Cardiol 1990, 16:862-870. | Article| PubMed

16. Bernini GP, Moretti A, Sgro M, Argenio GF, Barlascini CO, Cristofani R, Salvetti A: Influence of endogenous androgens on carotid wall in postmenopausal women. Menopause 2001, 8:43-50. | Article| PubMed

17. Williams MR, Dawood T, Ling S, Dai A, Lew R, Myles K, Funder JW, Sudhir K, Komesaroff PA: Dehydroepiandrosterone increases endothelial cell proliferation in vitro and improves endothelial function in vivo by mechanisms independent of androgen and estrogen receptors. $J$ Clin Endocrinol Metab 2004, 89:4708-4715. | Article| PubMed

18. Kawano $H$, Yasue $H$, Kitagawa A, Hirai N, Yoshida T, Soejima $H$, Miyamoto S, Nakano M, Ogawa H: Dehydroepiandrosterone supplementation improves endothelial function and insulin sensitivity in men. $J$ Clin Endocrinol Metab 2003, 88:3190-3195. | Article| PubMed

19. Rice SP, Agarwal N, Bolusani H, Newcombe R, Scanlon MF, Ludgate M, Rees DA: Effects of dehydroepiandrosterone replacement on vascular function in primary and secondary adrenal insufficiency: a randomized crossover trial. J Clin Endocrinol Metab 2009, 94:1966-1972. | Article| PubMed

20. Christiansen JJ, Andersen NH, Sorensen KE, Pedersen EM, Bennett $P$, Andersen M, Christiansen JS, Jorgensen JO, Gravholt CH: Dehydroepiandrosterone substitution in female adrenal failure: no impact on endothelial function and cardiovascular parameters despite normalization of androgen status. Clin Endocrinol (Oxf) 2007, 66:426-433. | Articlel PubMed

21. Marder W, Somers EC, Kaplan MJ, Anderson MR, Lewis EE, McCune WJ: Effects of prasterone (dehydroepiandrosterone) on markers of cardiovascular risk and bone turnover in premenopausal women with systemic lupus erythematosus: a pilot study. Lupus 2010, 19:12291236. | Article| PubMed

22. Labrie F, Luu-The V, Lin SX, Simard J, Labrie C, El-Alfy M, Pelletier G, Belanger A: Intracrinology: role of the family of $\mathbf{1 7}$ beta-hydroxysteroid dehydrogenases in human physiology and disease. $J$ Mol Endocrinol 2000, 25:1-16. | Article| PubMed

23. Liu D, Dillon JS: Dehydroepiandrosterone activates endothelial cell 
nitric-oxide synthase by a specific plasma membrane receptor coupled to Galpha(i2,3). J Biol Chem 2002, 277:21379-21388. Articlel PubMed

24. Montalcini T, Migliaccio V, Ferro Y, Gazzaruso C, Pujia A: Androgens for postmenopausal women's health? Endocrine 2012. | Article| PubMed

25. Simoncini T, Mannella P, Fornari L, Varone G, Caruso A, Genazzani AR: Dehydroepiandrosterone modulates endothelial nitric oxide synthesis via direct genomic and nongenomic mechanisms. Endocrinology 2003, 144:3449-3455. | Article| PubMed

26. Formoso G, Chen H, Kim JA, Montagnani M, Consoli A, Quon MJ: Dehydroepiandrosterone mimics acute actions of insulin to stimulate production of both nitric oxide and endothelin 1 via distinct phosphatidylinositol 3-kinase- and mitogen-activated protein kinasedependent pathways in vascular endothelium. Mol Endocrinol 2006, 20:1153-1163. | Article| PubMed

27. Liu D, Dillon JS: Dehydroepiandrosterone stimulates nitric oxide release in vascular endothelial cells: evidence for a cell surface receptor. Steroids 2004, 69:279-289. | Article| PubMed

28. Williams SB, Cusco JA, Roddy MA, Johnstone MT, Creager MA: Impaired nitric oxide-mediated vasodilation in patients with non-insulin-dependent diabetes mellitus. J Am Coll Cardiol 1996, 27:567-574. | Article| PubMed

29. Beckman JA, Creager MA, Libby P: Diabetes and atherosclerosis: epidemiology, pathophysiology, and management. JAMA 2002, 287:2570-2581. | Article| PubMed

30. Yamaguchi Y, Tanaka S, Yamakawa T, Kimura M, Ukawa K, Yamada Y, Ishihara $\mathrm{M}$, Sekihara $\mathrm{H}$ : Reduced serum dehydroepiandrosterone levels in diabetic patients with hyperinsulinaemia. Clin Endocrinol (Oxf) 1998, 49:377-383. | Article| PubMed

31. Arlt W, Justl HG, Callies F, Reincke M, Hubler D, Oettel M, Ernst M, Schulte HM, Allolio B: Oral dehydroepiandrosterone for adrenal androgen replacement: pharmacokinetics and peripheral conversion to androgens and estrogens in young healthy females after dexamethasone suppression. J Clin Endocrinol Metab 1998, 83:1928-1934. | Articlel PubMed

32. Arlt W, Haas J, Callies F, Reincke M, Hubler D, Oettel M, Ernst M, Schulte $\mathrm{HM}$, Allolio B: Biotransformation of oral dehydroepiandrosterone in elderly men: significant increase in circulating estrogens. J Clin Endocrinol Metab 1999, 84:2170-2176. | Article| PubMed

33. Nair KS, Rizza RA, O'Brien P, Dhatariya K, Short KR, Nehra A, Vittone JL, Klee GG, Basu A, Basu R, Cobelli C, Toffolo G, Dalla Man C, Tindall DJ, Melton LJ, 3rd, Smith GE, Khosla S, Jensen MD: DHEA in elderly women and DHEA or testosterone in elderly men. $N$ Engl $J$ Med 2006, 355:1647-1659. | Article| PubMed

34. Charalampopoulos I, Alexaki VI, Lazaridis I, Dermitzaki E, Avlonitis N, Tsatsanis C, Calogeropoulou T, Margioris AN, Castanas E, Gravanis A: $G$ protein-associated, specific membrane binding sites mediate the neuroprotective effect of dehydroepiandrosterone. FASEB J 2006, 20:577-579. | Article| PubMed

35. Molinari C, Battaglia A, Grossini E, Mary DA, Vassanelli C, Vacca G: The effect of dehydroepiandrosterone on regional blood flow in prepubertal anaesthetized pigs. J Physiol 2004, 557:307-319. | Article| PubMed Abstract | PubMed Full Text

36. Molinari C, Battaglia A, Grossini E, Mary DA, Vassanelli C, Vacca G: The effect of dehydroepiandrosterone on coronary blood flow in prepubertal anaesthetized pigs. J Physiol 2003, 549:937-944. | Article| PubMed Abstract | PubMed Full Text

37. Fulghesu AM, Romualdi D, Di Florio C, Sanna S, Tagliaferri V, Gambineri A, Tomassoni F, Minerba L, Pasquali R, Lanzone A: Is there a dose-response relationship of metformin treatment in patients with polycystic ovary syndrome? Results from a multicentric study. Hum Reprod 2012, 27:3057-3066. | Article| PubMed
38. Haffner SM, Valdez RA, Morales PA, Hazuda HP, Stern MP: Decreased sex hormone-binding globulin predicts noninsulin-dependent diabetes mellitus in women but not in men. J Clin Endocrinol Metab 1993, 77:56-60. | Article| PubMed

39. Barrett-Connor E, Goodman-Gruen D: Prospective study of endogenous sex hormones and fatal cardiovascular disease in postmenopausal women. BMJ 1995, 311:1193-1196. | Article| PubMed Abstract | PubMed Full Text

40. Haffner SM, Newcomb PA, Marcus PM, Klein BE, Klein R: Relation of sex hormones and dehydroepiandrosterone sulfate (DHEA-SO4) to cardiovascular risk factors in postmenopausal women. Am J Epidemiol 1995, 142:925-934. | Article| PubMed

41. Creatsa M, Armeni E, Stamatelopoulos K, Rizos D, Georgiopoulos G, Kazani M, Alexandrou A, Dendrinos S, Augoulea A, Papamichael C, Lambrinoudaki I: Circulating androgen levels are associated with subclinical atherosclerosis and arterial stiffness in healthy recently menopausal women. Metabolism 2012, 61:193-201. | Article| PubMed 